\title{
Functional implications of the form of Codium bursa, a balloon-like Mediterranean macroalga
}

\author{
Ole Geertz-Hansen ${ }^{1}$, Susana Enríquez ${ }^{2}$, Carlos M. Duarte ${ }^{2, *}$, Susana Agustí ${ }^{2}$, \\ Dolors Vaqué ${ }^{3}$, Beatriz Vidondo ${ }^{2}$
}

\author{
${ }^{1}$ Freshwater Biological Laboratory, University of Copenhagen, 51 Helsingørsgade, DK-3400 Hillerød, Denmark \\ ${ }^{2}$ Centre d'Estudis Avançats de Blanes, CSIC, Camí de Sta Bàrbara s/n, E-17300 Blanes, Girona, Spain \\ ${ }^{3}$ Institut de Ciències del Mar, CSIC, Passeig Joan de Borbó, Comte de Barcelona, E-08039 Barcelona, Spain
}

\begin{abstract}
The constraints imposed by the geometry of Codium bursa, a balloon-like Mediterranean macroalga with a thick $(\approx 5.6 \mathrm{~mm})$ thallus enclosing a lumen filled with water, on its functional properties were tested by examining the scaling of its form, composition (pigmentation and nutrient content), light absorption, metabolism (respiration rate, light use efficiency, and maximal photosynthetic rate), and growth to individual size. We found that $C$. bursa absorbs most (98\%) of the incident light, due to its high areal pigment density $\left(0.52 \mu \mathrm{g} \mathrm{chl} a \mathrm{~mm}^{-2}\right)$, but that light absorption was very inefficient, as seen from the low values of absorption per unit carbon $\left(0.045 \mathrm{~m}^{2} \mathrm{~g}^{-1} \mathrm{C}\right)$, which suggest a low intrinsic growth rate. The pigment and nutrient content of $C$. bursa increase more slowly than the macroalgal weight, so that large $C$. bursa balloons have lower pigment and nutrient contents than smaller individuals. As a consequence, photosynthetic capacity declines with increasing size, and light compensation points increase with increasing individual size, suggesting increasing light requirements and reduced potential growth rate as C. bursa grows. This was confirmed by in situ estimates of growth rate that showed $C$. bursa to rank amongst the slowest-growing macroalgae (specific growth rate $1.8 \pm 0.3 \times 10^{-3} \mathrm{~d}^{-1}$ ) as well as by the significant decline of specific growth rate with increasing algal size. The results obtained confirm the slow growth rates and the strong size-dependence of biochemical composition and metabolism imposed by the spherical geometry of C. bursa.
\end{abstract}

KEY WORDS: Macroalgal form - Function · Growth

\section{INTRODUCTION}

Comparative analyses of functional properties of marine algae have identified their form as a major determinant of their performance (Ramus 1978, 1990 , Littler 1980, Littler \& Littler 1980, Reynolds 1984, Wallentinus 1984, Lüning \& Dring 1985, Enríquez 1993 Duarte 1994, Enríquez et al. 1994). The smallest eucaryotic algae are often spherical but larger unicellular (Lewis 1976, Reynolds 1984) and, in particular, multicellular algae deviate from this simple shape. This deviation allows larger surface-to-volume ratios, thereby improving fluxes of nutrients, gas, and light across their surfaces (Lewis 1976, Reynolds 1984).

-Addressee for correspondence
There are, however, some remarkable exceptions to the observed tendency of an increased flatness with increasing algal size. Several unicellular algal groups produce large $(>0.1 \mathrm{~mm}$ ) spherical colonies (e.g. Synura spp., Volvox spp., Phaeocystis spp.), and there are also large, quasi-spherical macroscopic unicellular macroalgae, such as the large (up to $4 \mathrm{~cm}$ cell size) Valonia spp. (Taylor 1960). Among the multicellular macroalgae, the Mediterranean chlorophyte Codium bursa J. Agardh is exceptional because it forms balloons (Fig. 1) up to $40 \mathrm{~cm}$ in diameter (E. Ballesteros unpubl. obs.), with a thick algal wall enclosing a substantial water volume. Its unusual size and shape make C. bursa an excellent test organism to demonstrate the importance of thallus form and thickness as a constraint to macroalgal functional properties. 


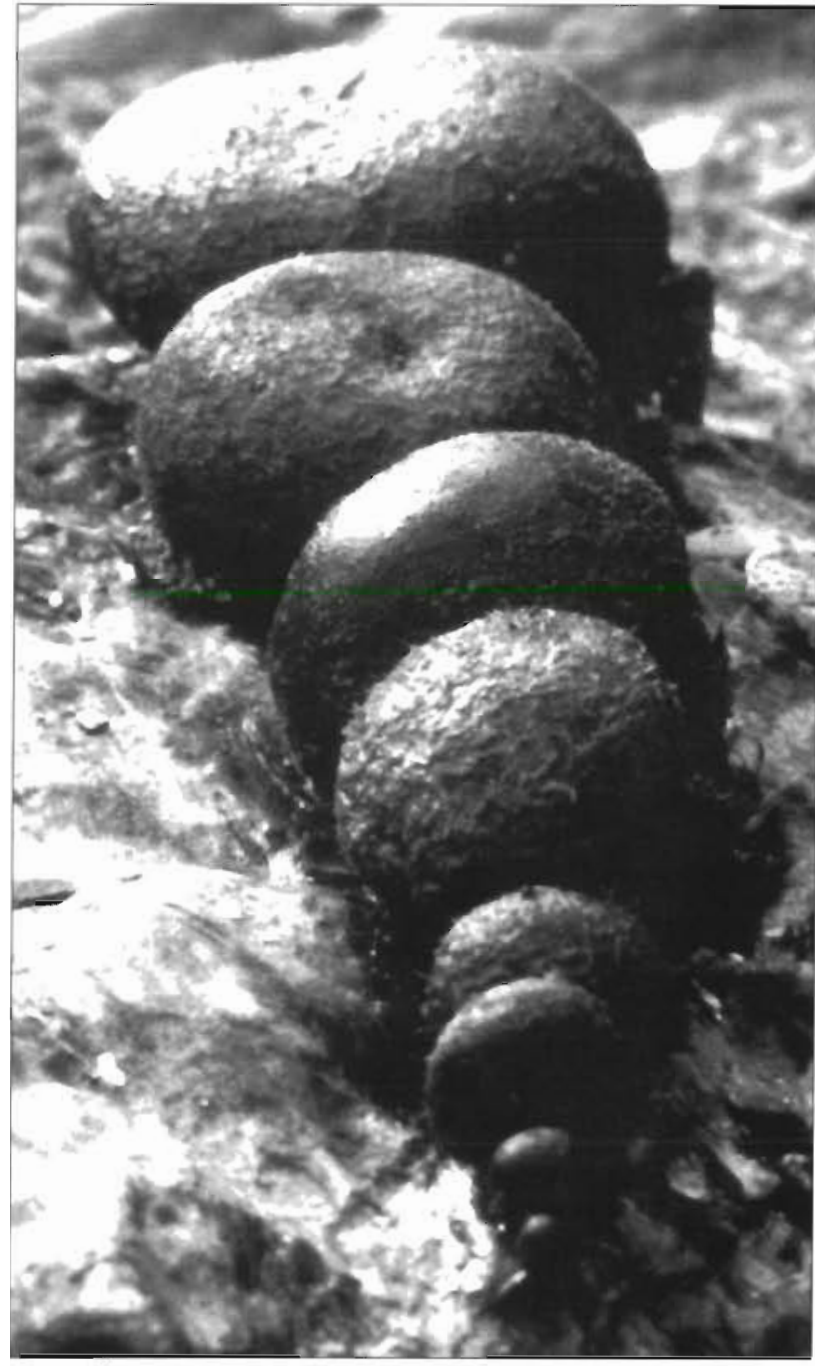

Fig. 1. Codium bursa. Form and size variability. The largest individual is ca $25 \mathrm{~cm}$ in diameter

Codium bursa has a wide size range (Fig. 1). Small C. bursa individuals should contain little or no (if diameter $\approx 2 \times$ thallus thickness) water. As individuals become larger, their interior becomes filled with water, and the algal thallus that forms the surface of the balloon should increase as the square of the individual diameter, whereas the volume of water inside will increase as the third power of the diameter. Hence, the relative contribution of macroalgal tissue should decline as the inverse of their diameter. We hypothesise, therefore, that functional properties of $C$. bursa should be strongly constrained by its peculiar geometry. The organism should, because of its thickness, have low light absorption per unit carbon and high minimum light requirements (Ramus 1978, 1990, Lüning \& Dring 1985, Enriquez 1993, Markager 1993, Agustí et al. 1994, Duarte 1994), Low potential growth rates (Nielsen \& Sand-Jensen 1990, Ramus 1990, Agustí et al, 1994, Duarte 1994), and a poor nutrient uptake capacity (Rosenberg \& Paerl 1981, Wallentinus 1984). We test here the hypothesised functional importance of the peculiar form of $C$. bursa by examining the scaling of its form, composition (pigmentation and nutrient content), light absorption, metabolism (respiration rate, light use efficiency, and maximal photosynthetic rate), and growth as a function of size.

\section{METHODS}

The study was conducted in November 1992 and 1993 using macroalgae collected in Cala Junquet, a small, shallow cove in the NW Mediterranean $\left(42^{\circ} 18.26^{\prime} \mathrm{N}, 3^{\circ} 18.11^{\prime} \mathrm{E}\right)$. The organisms collected grew attached to a rocky platform at 2 to $5 \mathrm{~m}$ water depth. We first estimated the density and biomass of macroscopic (>3 $\mathrm{mm}$ in diameter) Codium bursa by collecting, using SCUBA, all individuals within 14 randomly placed $0.25 \mathrm{~m}^{2}$ quadrats. We then collected about 200 additional specimens of $C$. bursa encompassing the widest possible size range for use in laboratory experiments. A subsample of the additional specimens was used to collect in situ samples of the enclosed water for analysis of dissolved nutrient concentration. The nutrient samples were preserved with a few drops of chloroform solution and kept frozen until analysis. The remaining specimens were transported in seawater maintained close to in situ water temperature $\left(17^{\circ} \mathrm{C}\right)$ to the laboratory, where they were kept at $17^{\circ} \mathrm{C}$ on a $12: 12 \mathrm{~h}$ day-night cycle in an incubator until the experiments. The growth of $C$. bursa was measured using a plant marking technique, by labelling $55 \mathrm{C}$. bursa specimens ranging in size from 1 to $15 \mathrm{~cm}$ with a numbered float directly attached to the thick $C$. bursa thallus or to a nail next to the smaller $(<4 \mathrm{~cm})$ specimens. All the specimens marked were measured, to the nearest $0.2 \mathrm{~mm}$, at the start of the experiment and after $34 \mathrm{~d}$ using a calliper. Specific growth rates $(\mu)$ were calculated from the increase in algal size over the measurement period using the equation

$$
\mu=\frac{\ln \left(\frac{W_{t}}{W_{0}}\right)}{t}
$$

where $t$ is the duration (in days) of the measurement period, and $W_{t}$ and $W_{0}$ are the final and initial dry weight of the specimens, respectively. Dry weights were estimated from the linear dimension measured using a regression equation $\left(R^{2}=0.99\right)$.

At the laboratory, we measured the displacement volume and the fresh weight of the intact individuals and, after removing the enclosed water, the weight of 
the macroalgal thallus. Subsamples of the thalli were dried at $85^{\circ} \mathrm{C}$ to calculate their water content, and subsequently combusted at $440^{\circ} \mathrm{C}$ to determine their ash content. The displacement volume was used to calculate the equivalent spherical diameter (ESD), which provides a convenient estimate of the characteristic linear dimension of organisms. A subsample of individuals spanning a wide range of size was used to measure thallus thickness, specific area, light absorption, pigmentation, carbon, nitrogen, and phosphorus content. The thallus thickness was determined under a dissecting microscope and a section of known area was dried to calculate its specific area $\left(\mathrm{mm}^{2} \mathrm{mg}^{-1} ; 1\right.$-sided measurement). Light absorption by the thalli was measured at $1 \mathrm{~nm}$ intervals from 400 to $750 \mathrm{~nm}$ by fitting fragments of tissue, cleaned of epiphytes, in the spectrophotometer cuvette of a Shimadzu UV-2100 dualbeam scanning spectrophotometer. We used the opal glass technique to avoid scattering artefacts that lead to an overestimation of light absorption (Shibata 1959), and corrected our measurements by subtracting absorbance at $750 \mathrm{~nm}$ from those measured within the PAR range to exclude non-pigment absorption and residual back scattering (Duysens 1956, Stramski 1990). The measurements with the opal glass technique were calibrated against measurements with an integrating sphere (Enriquez et al, 1994). Light absorption is reported as absorptance (i.e. fractional light absorbed by pigments), which was calculated from absorbance estimates using the equation (Clayton. 1973)

$$
\text { Absorptance }=1-10^{- \text {absorbance }}
$$

Chlorophyll $a, b$, and carotenoid concentrations were measured spectrophotometrically, on the same fragments used for light absorption, following pigment extraction with $80 \%$ acetone in a homogenised suspension (Dennison 1990). Tissue carbon and nitrogen concentrations were determined for duplicate subsamples (4 mg dry wt each), using a Carlo-Erba CHN analyser, while phosphorus concentrations were determined colorimetrically in duplicate subsamples $18 \mathrm{mg}$ dry wt each) following wet acid digestion (Koroleff 1983). Coefficients of variation of the duplicate analyses were $1 \%$ for $\mathrm{C}$ and $\mathrm{N}$, and $6 \%$ for $\mathrm{P}$. As the CHN analyser does not distinguish between organic and inorganic carbon, the content of inorganic carbon precipitated as carbonate or bicarbonate in the thallus was determined separately in an open Infrared Gas Analysing system (IRGA, ADC 225 Mk 3). Small samples $(200 \mu \mathrm{l})$ of suspensions containing $200 \mu \mathrm{g}$ of pulverised algae were acidified in a bubbling chamber and the released $\mathrm{CO}_{2}$ gas was carried into the IRGA by a flow of $\mathrm{N}_{2}$ gas. Nutrient concentrations (nitrate, nitrite, ammonia, and phosphate) of the enclosed, and ambient, water were analysed colorimetrically on an autoanalyzer following Strickland \& Parsons (1972).

Photosynthesis-irradiance (P-I) curves for Codium bursa were examined between 0 and $650 \mu \mathrm{mol}$ photons $\mathrm{m}^{-2} \mathrm{~s}^{-1}$ on 8 intact individuals $(2.4$ to $13.6 \mathrm{~cm}$ in diameter). The plant material was placed in a perspex chamber equipped with a Clark-type oxygen electrode and maintained at $17^{\circ} \mathrm{C}$ by circulating water in a cooling jacket. In large chambers holding intact individuals mixing was provided by a submersible pump. A magnetic stirrer was used in a smaller chamber $(5 \mathrm{ml}$ volume) holding thallus sections. Oxygen signals were sampled every minute with a Li-Cor data logger. We avoided possible errors deriving from significant oxygen exchange between large thalli and the water they enclose by simultaneously measuring the time course of oxygen concentration with a second Clark-type oxygen electrode in the internal water, using a peristaltic pump

We examined the size-dependence of the biochemical and metabolic properties, and algal growth $(Y)$ by allometric relations to the dry weight of the thallus of Codium bursa individuals (Weight, $g$ dry wt ind.$^{-1}$ ).

$$
Y=a \text { Weight }^{b}
$$

The allometric equations were fitted using least squares linear regression analyses on log-transformed variables (LaBarbera 1989). Regression slopes (b) significantly ( $t$-test, $\mathrm{p}<0.05$ ) smaller than 1 indicate that the property examined declines, relative to the weight of the algal thallus, with increasing algal size. We also used Pearson correlation coefficients to examine directly the relationship between the relative values of the properties examined, standardised to algal weight or surface area, and algal size (dry wt). We shall refer to the whole $C$. bursa balloon (i.e. algal thallus plus the water enclosed) as an 'individual' to differentiate it from the algal wall.

\section{RESULTS AND DISCUSSION}

Codium bursa had a very patchy distribution in Cala Junquet. The average density was $51.7 \pm 18.2( \pm \mathrm{SE})$ ind. $\mathrm{m}^{-2}$ and the average biomass was $284 \pm 73 \mathrm{~g}$ dry wt of macroalgal tissue $\mathrm{m}^{-2}$ The organisms ranged widely in size (Table 1), with $50 \%$ of the organisms being less than $5 \mathrm{~cm}$ in ESD.

Codium bursa is a very thick macroalga. The thallus wall tended to grow thicker with increasing size, from about $4 \mathrm{~mm}$ in small individuals to about $6 \mathrm{~mm}$ in the largest individuals (Table 1). About $50 \%$ of the organismal weight was represented, on average, by the water it enclosed (Table 1). This proportion increased with organismal size, because the volume of 
Table 1 Codium bursa. Mean, standard error, range, and sample size $(\mathrm{n})$ for the different measured properties and their correlation coefficient $(r)$ with the dry weight of the macroalgal thallus. $p<0.05$

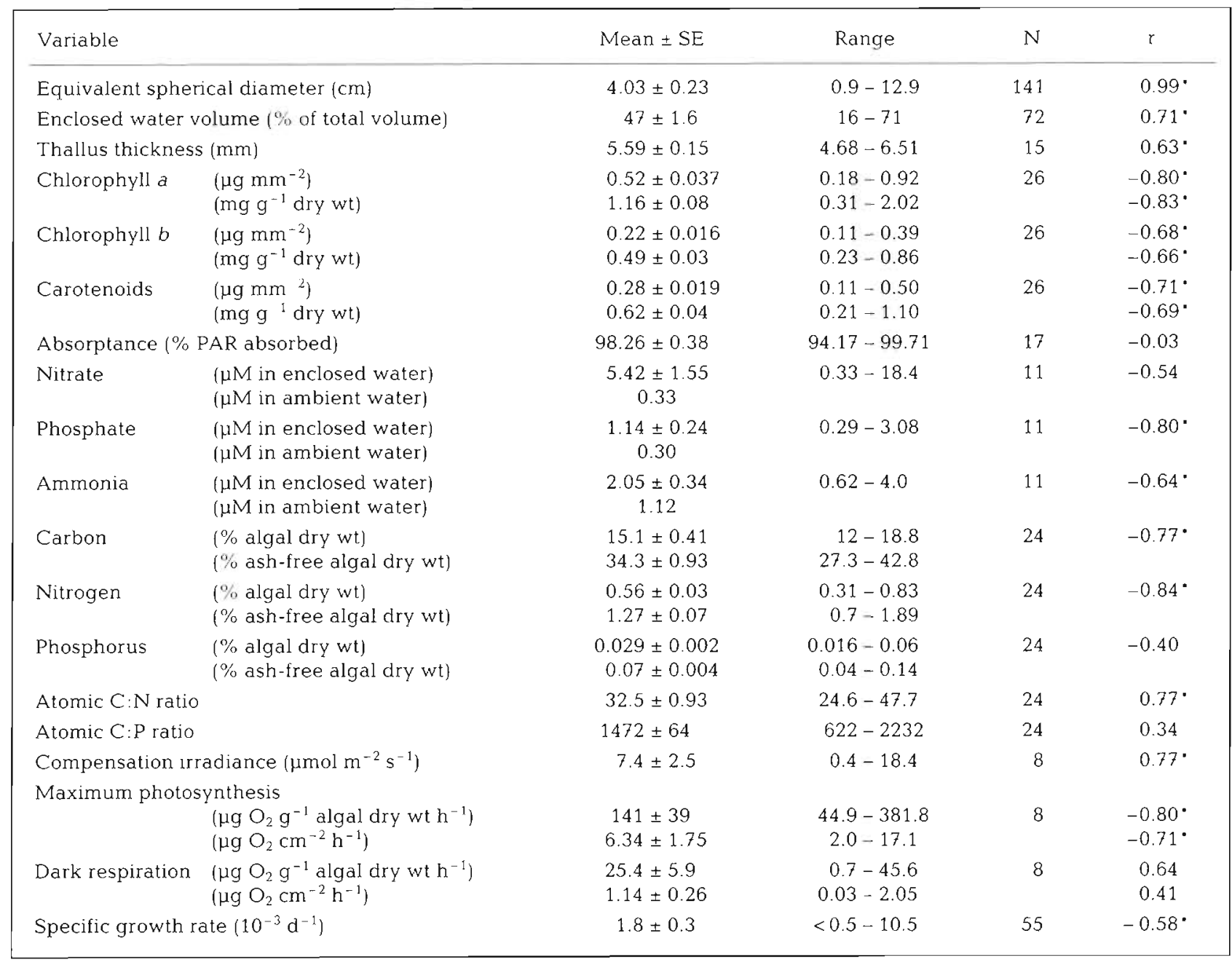

Table 2. Codium bursa. Allometric equations describing the scaling of different properties $(Y)$ of intact individuals to the weight of the algal thallus ( $g$ dry $w t$ ). The equations were calculated using least squares regressions of the form $Y=a$ Weight ${ }^{b}$ Also shown are the standard error of the slope $(b)$ estimates, the coefficient of determination $\left(\mathrm{R}^{2}\right)$, the F-statistic and associated probability level (p), and the number of observations $(\mathrm{n})$. The symbol ${ }^{\bullet}$ indicates regression slopes $(b)$ significantly $(\mathrm{p}<0.05)$ smaller than 1 , indicative that the property declines, relative to the weight of the algal thallus, with increasing algal size

\begin{tabular}{|c|c|c|c|c|c|c|}
\hline Property & a & $b$ & $\mathrm{R}^{2}$ & $F$ & $\mathrm{p}$ & n \\
\hline Enclosed water volume $\left(\mathrm{cm}^{3}\right.$ ind.$\left.^{-1}\right)$ & 0.67 & $1.21 \pm 0.02$ & 0.99 & 2316 & $<0.0001$ & 71 \\
\hline Chlorophyll a (mg ind. ${ }^{-1}$ ) & 0.12 & $0.85 \pm 0.02^{\circ}$ & 0.98 & 1128 & $<0.0001$ & 26 \\
\hline Chlorophyll $b$ (mg ind. ${ }^{-1}$ ) & -0.26 & $0.89 \pm 0.02^{\circ}$ & 0.98 & 1334 & $<0.0001$ & 26 \\
\hline Carotenoids (mg ind..$^{-1}$ ) & -0.16 & $0.88 \pm 0.02$ & 0.98 & 1307 & $<0.0001$ & 26 \\
\hline Nitrate in enclosed water ( $\mu \mathrm{mol}$ ind.$^{-1}$ ) & -1.30 & $0.94 \pm 0.16$ & 0.77 & 32 & $<0.0005$ & 11 \\
\hline Phosphate in enclosed water ( $\mu \mathrm{mol}$ ind.$^{-1}$ ) & -1.91 & $0.93 \pm 0.07$ & 0.95 & 186 & $<0.0001$ & 11 \\
\hline Ammonia in enclosed water $\left(\mu \mathrm{mol}\right.$ ind.$\left.^{-1}\right)$ & -1.77 & $1.00 \pm 0.10$ & 0.91 & 93 & $<0.0001$ & 11 \\
\hline Carbon content (g ind.$^{-1}$ ) & -0.82 & $0.95 \pm 0.01$ & 0.99 & 13472 & $<0.0001$ & 24 \\
\hline Nitrogen content (mg ind. ${ }^{-1}$ ) & 0.77 & $0.89 \pm 0.01^{\circ}$ & 0.99 & 3417 & $<0.0001$ & 24 \\
\hline Phosphorus content (mg ind. ${ }^{-1}$ ) & -0.54 & $0.93 \pm 0.02$ & 0.97 & 1457 & $<0.0001$ & 24 \\
\hline$P_{\max }\left(\mu g O_{2}\right.$ ind $\left.^{-1} h^{-1}\right)$ & 2.24 & $0.75 \pm 0.08^{\circ}$ & 0.93 & 86 & $<0.0001$ & 8 \\
\hline Dark respiration ( $\mu \mathrm{g} \mathrm{O}_{2}$ ind $^{-1} \mathrm{~h}^{-1}$ ) & 0.98 & $1.24 \pm 0.26$ & 0.75 & 22 & $<0.005$ & 8 \\
\hline Growth rate (g dry wt ind ${ }^{-1} \mathrm{~d}^{-1}$ ) & -2.58 & $0.74 \pm 0.05^{\circ}$ & 0.84 & 167 & $<0.0001$ & 33 \\
\hline
\end{tabular}


water enclosed within $C$. bursa increased faster than algal weight (Table 2). Very small organisms lack an internal cavity, and the weight of water enclosed, relative to the weight of the algal thallus, increased linearly with increasing algal size to reach $80 \%$ of the total weight for individuals of about $8 \mathrm{~cm}$, but did not increase beyond this, indicating that larger individuals become increasingly elongated.

Codium bursa thalli had a high areal pigment density, exceeding the levels needed to absorb $90 \%$ of the incident light (Agustí et al. 1994), but pigment concentrations per unit weight were low (Table 1), as expected for a thick plant (Agustí et al. 1994). The pigment content of $C$. bursa individuals increased slower than algal weight did (Table 2, Fig. 2), indicating that the pigment concentration, whether expressed per unit area or algal weight, declines with increasing organismal size (Table 1, Fig. 3). Yet, the areal pigment density was sufficient to allow $C$. bursa thalli to absorb most of the incident light (Table 1), and, therefore, the species would not benefit from a substantial increase in light absorption by increasing their chlorophyll density (Ramus 1978, Agustí et al. 1994). Hence, we found no significant relationship ( $r=0.10, p=0.74$ ) between the areal chlorophyll $a$ density and the fraction of light harvested by $C$. bursa. Variability in light harvesting in thick organisms may be attributable to other factors such as structural complexity. For example, the large utricula of Codium spp. have been postulated to increase, through multiple scattering, the effective pathlength of photons across the organism (e.g. Ramus $1978,1990)$. In addition, we found large numbers of crystals, identified by X-ray diffraction microscopy to be mostly calcium sulphate (average atomic composition $36.9 \pm 2.1 \% \mathrm{Ca}, 38.7 \pm 2.7 \%$ S), that contribute to the large ash content ( $56 \pm 7 \%$ of dry weight) of the algal thallus, with carbonates representing a minor $(<0.01 \%)$ component of the dry weight of the tissues. The calcium sulphate crystals must increase internal scattering, thereby contributing to the ability of the $C$. bursa thallus to act, essentially, as a black body. Despite the ability of the organism to harvest most of the incident light, the light absorption per unit weight of carbon is low (average $0.045 \mathrm{~m}^{2} \mathrm{~g}^{-1} \mathrm{C}$ ), indicating a low growth potential (Ramus 1990, Enríquez 1993, Agustí et al. 1994).

The inefficient light capture may not be the sole constraint on Codium bursa growth. The thickness of the organisms results in a low surface-to-volume ratio, and its peculiar geometry implies that only 1 side of the macroalgal surface is exposed to the ambient water. This suggests that uptake rate of solutes should be low (cf. Wallentinus 1984), something previously demonstrated for congeneric species (Rosenberg \& Paerl 1981). Evidence for a low uptake rate was supported by the low concentrations of nitrogen and, particularly,
Fig. 2. Codium bursa. Relationship between the weight of individuals and their chlorophyll $a$ and nitrogen content, maximum photosynthetic rate, and growth rate. Solid lines represent the regression equations in Table 2
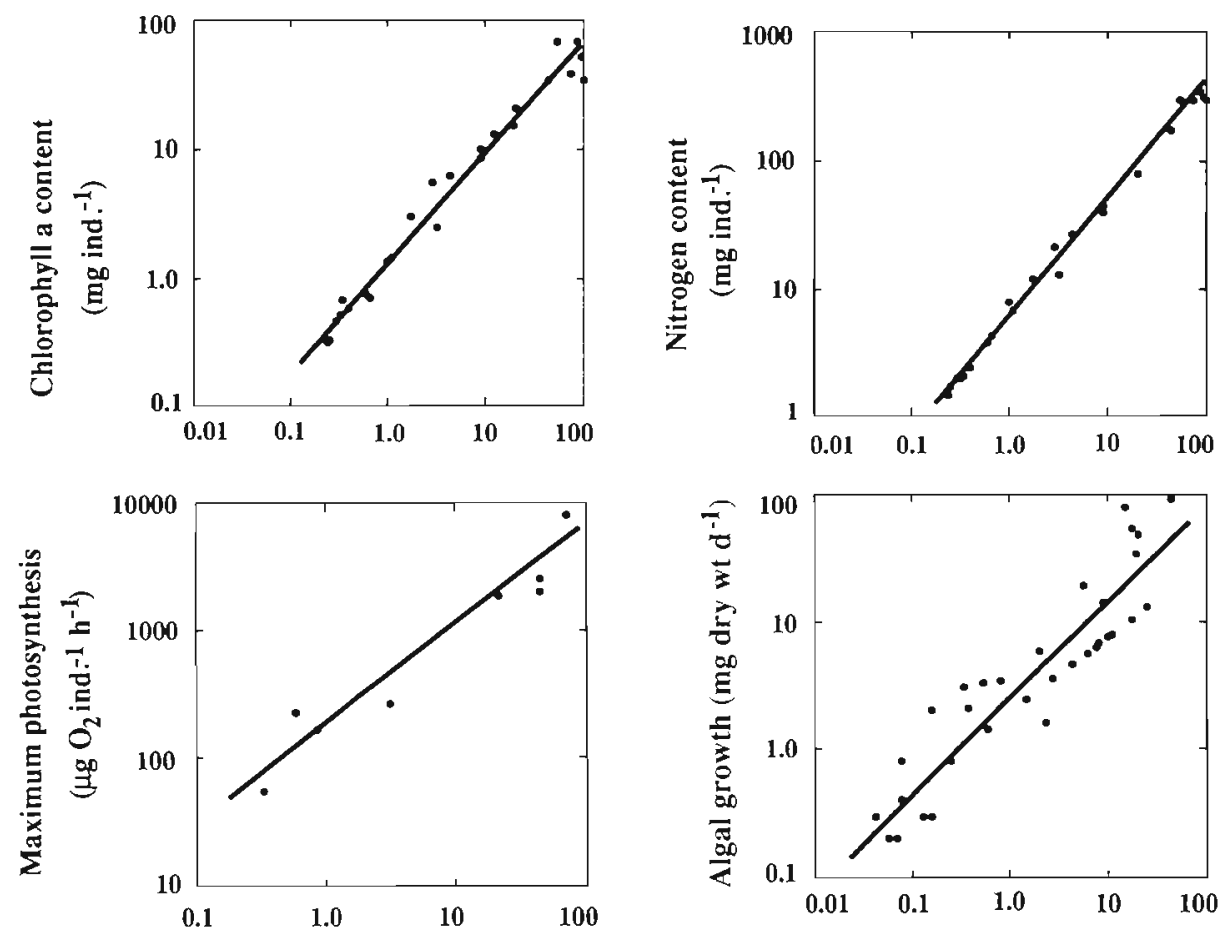

Algal weight (g dry wt ind..$^{-1}$ ) 

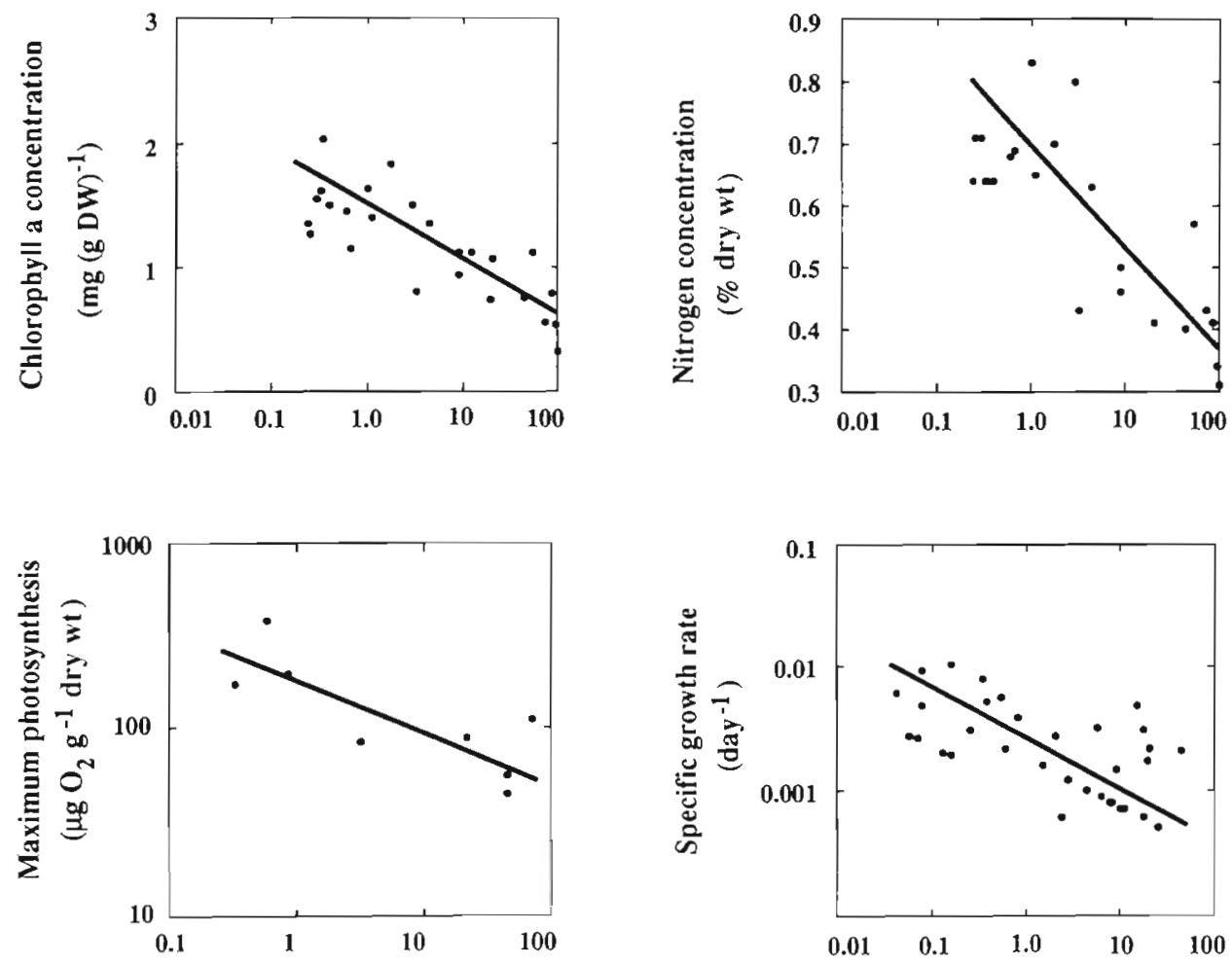

Fig. 3. Codium bursa. Relationship between the weight of individuals and their chlorophyll $a$ and nitrogen concentration, maximum photosynthetic rate per unit weight, and specific growth rate. Solid lines represent the regression equations fitted to the data

Algal weight (g dry wt ind.-1)

phosphorus within the tissues, which was close to the minimum values observed for macroalgae (Duarte 1992) (Table 1). In addition, the average $C: P$ ratio of the thalli (Table 1) was amongst the highest reported for macroalgae (Duarte 1992), suggesting an acute phosphorus shortage, even considering the low potential growth rate expected of this organism.

Codium bursa may satisfy part of its nutrient demand by an efficient nutrient retention and recycling within the enclosed water, because nutrient concentrations of the internal water (Table 1) were 2- to 10-fold higher than ambient levels, such that the internal surface of the macroalgae is in contact with greater nutrient concentrations than the external one. The high nutrient concentrations inside $C$. bursa balloons likely result from recycling by the active microbial food web they contain (Vaqué et al. 1994). The concentrations of dissolved inorganic nutrients, particularly phosphate and ammonia, in the internal lumen tend to decline with increasing individual size (Table 1), which may be attributed to the combined effect of reduced macroalgal weight relative to internal water volume and a reduced microbial activity (Vaqué et al. 1994).

The nutrient content of the thalli also increased slower than thallus weight (Fig. 2, Table 2), indicating that large thalli tend to have reduced nutrient concentrations (Table 1). The decline was steepest for nitro- gen (Fig. 3), and, hence, C:N ratios, but not C: $\mathrm{P}$ ratios, increased significantly with increasing Codium bursa size (Table 1). Yet, $\mathrm{C}: \mathrm{P}$ ratios were so high (Table 1) that nitrogen should play a small role relative to phosphorus in controlling plant growth. This is consistent with the presence of a disproportionately larger pool of inorganic nitrogen in the enclosed water, relative to ambient concentrations, compared to that of phosphorus (Table 1).

Measurements of photosynthesis and respiration revealed remarkably low rates (Table 1), well below the values often reported for macroalgae (e.g. Ramus 1978, Littler 1980, Littler \& Arnold 1982, Enríquez 1993), indicative of a low potential carbon turnover. Although photosynthetic rates were low, Codium bursa is able to maintain a small positive carbon balance, as a result of a remarkably low dark respiration rate (Table 1), which allows a low light compensation point (Table 1). The low photosynthetic rates can be partially explained by the quasi-spherical shape of $C$. bursa, with individuals having a photosynthetic area index of $2 \mathrm{~m}^{2} \mathrm{~m}^{-2}$ and the top layer shading the base of the balloon. Despite the small sample size obtained for parameters describing P-I curves $(n=8)$, the data available suggested that maximal photosynthetic rates of entire individuals tend to increase as the $3 / 4$ power of algal weight (Table 2, Fig. 2), such that large individu- 
als achieve lower maximal photosynthetic rates, relative to the weight of their thalli, than small ones (Fig. 3 , Table 1). Because respiration rates tended to increase at the same rate as the weight of macroalgal thallus (Table 2), the reduced maximal photosynthesis of large individuals implies that these must grow even slower than small individuals. Moreover, the data available $(\mathrm{n}=8$ ) also suggested that large individuals tend to have higher light compensation points (Table 1), further reflecting their greater light requirements

Consistent with expectations, the growth rates measured in situ confirmed that Codium bursa is a slowgrowing organism: average specific growth rates were $1.8 \times 10^{-3} \mathrm{~d}^{-1}$ and average doubling times exceeded $1 \mathrm{yr}$ (Table 1). The growth rates measured for C. bursa place it amongst the slowest-growing macroalgae (cf. Fortes \& Lüning 1980, Nielsen \& Sand-Jensen 1990, Duarte 1994), and indicate that it must be a very long-lived organism, the largest organisms measured here likely exceeding a decade in age. The absolute growth of $C$. bursa was scaled, similar to the maximal photosynthetic rate, to the $3 / 4$ power of algal weight (Fig. 2, Table 2), and, as postulated from examination of P-I curve parameters, their specific growth rates tended to decline with increasing $C$. bursa size (Fig. 3, Table 1).

The results obtained demonstrate the dominant role of the balloon-like form and the thallus thickness of Codium bursa in their ecological performance. By growing as a thick-walled balloon, C. bursa has high areal pigment density that allows it to capture most of the incident light, but at the expense of having a low carbon-specific light absorption and, hence, low potential growth rates. Hence, $C$. bursa supports extremely low photosynthetic rates, with a positive carbon balance possible because of its unusually low respiration rates. This results in $C$. bursa ranking amongst the slowest-growing macroalgae, with large organisms growing even slower than small ones. That the scaling of algal growth to weight was similar to that of maximum photosynthesis further reflects the constraint that the low photosynthetic rate of $C$. bursa places on its growth. The low surface-to-volume ratios of the thick balloon-like $C$. bursa should have a strongly negative influence on its ability to capture nutrients from the ambient water (cf. Rosenberg \& Paerl 1981, Wallentinus 1984), reflected by the extremely low nitrogen and, particularly, phosphorus contents of the tissues, with its $C: P$ ratios being amongst the highest yet reported for marine macroalgae. These very high $C: P$ ratios are indicative of an acute phosphorus limitation, which could depress photosynthetic rates below the slow rates imposed by the shape of the organism, further reducing growth rates.

The very high biomass the alga is able to produce in the NW Mediterranean contrasts with its very slow growth rate and its poor competitive ability for critical nutrients and light, and must be achieved through minimising losses over the extended life span of this organism. This points to low resource requirements and reduced losses as the keys to the success of Codium bursa. The plant architecture allows for a highly effective nutrient conservation and recycling within the lumen by the microbial community growing there (Vaqué et al. 1994). These attributes, together with the large size of all but the smallest C. bursa, which provides a refuge from herbivores, appear sufficient to explain the ecological success of $C$. bursa and provide an extreme demonstration of the functional importance of thallus thickness and form for the ecology of macroalgae.

Acknowledgements. This work was supported by grant MAR91-0503 of CICYT (Spanish Interministerial Research Commission) to C.M.D. We thank Enrique Ballesteros for advice José Manuel Fortuño for assistance with electronic microscopy, and Kaj Sand-Jensen and Jaap Kalff for helpful criticism

\section{LITERATURE CITED}

Agustí, S., Enríquez, S., Frost-Christensen, H., Sand-Jensen, K., Duarte, C. M. (1994). Light harvesting by photosynthetic organisms. Functional Ecol. (in press)

Clayton, R. K. (1973). Light and living matter, Vol. 1. The physical part. McGraw-Hill, Montreal

Dennison, W. C. (1990). Chlorophyll content. In: Phillips, R. C., McRoy, P. (eds.) Seagrass research methods. UNESCO, Paris, p. 83-85

Duarte, C. M. (1992). Nutrient concentration of aquatic plants: patterns across species. Limnol. Oceanogr. 37: 882-889

Duarte, C. M. (1994). Submerged aquatic vegetation in relation to different nutrient regimes. Ophelia (in press)

Duysens, L. M. N. (1956). The flattening effect of the absorption spectra of suspensions as compared to that of solutions. Biochem. Biophys. Acta 19: 1-12

Enríquez, S. (1993). Continuo de variación en el funcionamiento de los organismos fototróficos. Un estudio comparativo. Ph.D. thesis, Univ. Autónoma de Madrid

Enríquez, S., Agustí, S., Duarte, C. M. (1994). Light absorption by marine macrophytes. Oecologia (in press)

Fortes, M. D., Lüning, K. (1980). Growth rates of North Sea macroalgae in relation to temperature, irradiance, and photoperiod. Helgoländer Meeresunters. 34: 15-29

Koroleff, F. (1983). Determination of phosphorus. In: Grasshoff, K., Erhardt, M., Kremling, K. (eds.) Methods of seawater analysis, 2nd edn. Verlag-Chemie, Nürnberg, p. $125-139$

LaBarbera, M. (1989). Analyzing body size as a factor in ecology and evolution. A. Rev. Ecol. Syst. 20: 97-117

Lewis, W. M. (1976). Surface/volume ratio: implication for phytoplankton morphology. Science 192: 885-887

Littler, M. M. (1980). Morphological form and photosynthetic perfomances of marine macroalgae: test of a functional/form hypothesis. Botanica mar. 23: 161-165

Littler, M. M., Littler, D. S. (1980). The evolution of thallus form and survival strategies in benthic marine macro- 
algae: field and laboratory test of a functional form model. Am. Nat. 116: 25-44

Littler, M. M., Arnold, K. E. (1982). Primary productivity of marine macroalgal functional-form groups from Southwestern North America. J. Phycol. 18: 307-311

Lüning, K., Dring, M. J (1985). Action spectra and spectral quantum yield of photosynthesis in marine macroalgae with thin and thick thalli. Mar. Biol. 87: 119-129

Markager, S. (1993). Light absorption and quantum yield for growth in five species of marine macroalgae. J. Phycol. 29: $54-63$

Nielsen, S. L., Sand-Jensen, K. (1990). Allometric scaling of maximal photosynthetic growth rate to surface/volume ratio. Limnol. Oceanogr. 35: 177-181

Ramus, J. (1978). Seaweed anatomy and photosynthetic perfomance: the ecological significance of light guides, heterogeneous absorption and multiple scatter. J. Phycol. 14: $352-362$

Ramus, J. (1990). A form-function analysis of photon capture for seaweeds. Hydrobiologia 204/205: 65-71

Reynolds, C. S. (1984). The ecology of freshwater phytoplankton. Cambridge Univ. Press, Cambridge

This article was submitted to the editor
Rosenberg, G., Paerl, H. W. (1981). Nitrogen fixation by bluegreen algae associated with the siphonous green seaweed Codium decorticatum: effects on ammonium uptake. Mar. Biol. 61: 151-158

Shibata, K. (1959). Spectrophotometry of translucence biological materials - opal glass transmission method. Meth. Biochem. Anal. 7: 77-109

Stramski, D. (1990). Artifacts in measuring absorption spectra of phytoplankton collected on a filter. Limnol. Oceanogr. 35: $1804-1809$

Strickland, J. D. H., Parsons, T. R. (1972). A practical handbook of seawater analysis, 2nd edn. Bull. Fish. Res. Bd Can. 167

Taylor, W. R. (1960). Marine algae of the eastern tropical and subtropical coasts of the Americas. Univ. of Michigan Press, Ann Arbor

Vaqué, D., Agustí, S., Duarte, C. M., Enríquez, S., GeertzHansen, O. (1994). Microbial heterotrophs within Codium bursa: a naturally isolated microbial food web. Mar. Ecol. Prog. Ser. (in press)

Wallentinus, I. (1984). Comparison of nutrient uptake rates for Baltic macroalgae with different thallus morphologies. Mar. Biol. 80: 215-225

Manuscript first received: November 30, 1993

Revised version accepted: March 10, 1994 